\title{
Penyuluhan Data Mining Dengan Ensemble Learning Dalam Strees Pembelajaran Sekolah Saat Covid19
}

\author{
Jajam Haerul Jaman ${ }^{1}$, Harry Dhika ${ }^{2}$ Iwan Hermawan ${ }^{3}$, Praditya Putri Utami ${ }^{4}$, \\ Fitriana Destiawati ${ }^{5}$ \\ 1,4 Fakultas Ilmu Komputer, Universitas Singaperbangsa Karawang \\ ${ }^{3}$ Fakultas Teknik dan Ilmu Komputer, Universitas Indraprasta PGRI \\ 2,5 Fakultas Agama Islam, Universitas Singaperbangsa Karawang \\ Email : jajam.haeruljaman@staff.unsika.ac.id, dhikatr@yahoo.com2, \\ iwan.hermawan@staff.unsika.ac.id3, praditya.putri@fkip.unsika.ac.id4, \\ honeyzone86@gmail.com5
}

\begin{abstract}
This community service has a high school object in Karawang City. This condition and location was chosen because of the initial study that had been carried out in the city of Karawang. In this paper, the application of ensemble learning as a determinant of learning stress can be relevant to the concept of learning during the Covid19 pandemic. Of course, online learning with software has been implemented first at that location, so the goal is to apply the concept of data mining with ensemble learning techniques for data mining learning. This paper focuses more on the current conditions during the Covid-19 pandemic, the application of data mining is carried out to help determine the level of learning stress. The results of this study are to provide knowledge and socialization to the parties involved from the results that have been carried out.
\end{abstract}

Keywords: Ensemble Learning, Data Mining, Covid19, Learning Stress, Senior Hight School.

\begin{abstract}
Abstrak
Pengabdian kepada masyarakat ini memiliki objek SMA di Kota Karawang. Kondisi dan lokasi ini dipilih karena kajian awal yang telah dilakukan di Kota Karawang. Pada makalah ini, penerapan pembelajaran ensambel sebagai penentu stres belajar dapat relevan dengan konsep pembelajaran selama pandemi Covid19. Hal ini sejalan dengan beratnya pemebelajaran online dimana dibebani dengan berbagai tugas dan pengetahuan baru tentang teknologi khususnya penggunaan aplikasi seperti zoom dsb. Tentunya pembelajaran daring dengan software telah diterapkan terlebih dahulu di lokasi tersebut, sehingga tujuannya adalah untuk menerapkan konsep penambangan data dengan teknik pembelajaran ensambel untuk pembelajaran data mining. Penambangan data dilakukan untuk mengetahui tingkat stress siswa selama pembelajaran berlangsung sehingga pihak sekolah dapat mengambil tindakan pemulihan perlahan selama pembelajaran dimulai berikutnya. Makalah ini lebih berfokus pada kondisi saat ini selama pandemi Covid-19, penerapan penambangan data dilakukan untuk membantu menentukan tingkat stres pembelajaran. Hasil penelitian ini adalah memberikan pengetahuan dan sosialisasi kepada pihak-pihak yang terlibat dari hasil yang telah dilakukan.
\end{abstract}

Kata kunci: Ensemble Learning, Data Mining, Covid19, Learning Stress, SMA

\section{PENDAHULUAN}

Pengabdian kepada masyarakat ini memiliki objek sekolah menengah atas di kota Karawang. Kondisi dan lokasi ini dipilih karena studi pendahuluan yang telah dilakukan pada kota bogor dimana kajian ini merupakan tindak lanjut dari penelitian terdahulu mengenai perancangan aplikasi elearning yang di berikan pada sekolah di kota Karawang. Selain lingkungan kota Karawang yang mengalami zona merah akibat pandemic Covid19, Covid19 merupakan virus yang sangat menular saat ini (Rowan \& Laffey 2020) virus ini juga merupakan RNA strain tunggal yang dapat mengganggu saluran pernapasan(Gellysa Urva et al. 2021), tentunya pembelajaran online dengan perangkat lunak telah diterapkan terlebih dahulu pada lokasi tersebut, sehingga tujuan kajian ini menerapkan konsep data mining dengan teknik ensemble learning untuk pembelajaran data mining. Pengabdian kepada masyarakat yang telah dilakukan pada 
rekanan yakni memberikan perangkat lunak untuk SMA di wilayah Karawang sehingga terjadi transisi dari pembelajaran manual kedalam konsep e-learning. Apa yang telah diterapkan akan dilakukan pembahasan dengan pihak sekolah demi melakukan pembelajaran data mining, adapun kegiatan penelitian mengahasilkan sebuah rule atau model basic dan menghasilkan pembelajaran ensemble learning dari konsep data mining. Model atau rule tersebut akan di berikan pada pihak sekolah untuk mengetahui tingkat stress pada pembelajaran di sekolah dengan beberapa attribut atau kondisi sekolah. Berbagai teknik sebenarnya telah dikembangkan seperti AI (Ardakani et al. 2020) pada kajian ini lebih fokus pada penerapan pembelajaran data mining, namun sebagai tindak lanjut dari kajian sebelumnya yakni mengenai pembelajaran online dan literasi digital. Kajian ini lebih di titik beratkan pada kondisi saat ini dalam masa pandemic Covid19 dilakukan penerapan data mining untuk membantu mengetahui tingkat stress pembelajaran. Hal ini masih sangat baru karena kejadian wabah atau pandemic Covid19 baru saja terjadi di dunia dan masih sangat hangat sekali seluruh kajian diarahkan untuk menyelesaikan masalah ini.

Pengabdian kepada masyarakat ini memberikan antisipasi mengenai salah satu bagian kecil dari percepatan penyelesaian wabah Covid19 dalam bidang keilmuan data mining serta bidang pendidikan. Hal ini menjadi sangat penting dengan kondisi seluruh sekolah yang di tutup dan seluruh siswa yang belajar di rumah. Diharapkan kontribusi keilmuan dalam kajian ini terletak pada ranah utama yakni data mining dengan teknik ensemble learning. Kemudian berkontribusi juga pada bidang pendidikan terhadap situasi pandemic Covid19. Dengan begitu membuka paradigma pembelajaran pada sekolah sesuai program pemerintah saat ini dengan konsepnya merdeka belajar. Luaran dari kegiatan pengabdian ini pada mitra kami adalah jasa penyuluhan rule atau metode dalam mengatasi stress pembelajaran ketika masa pandemi Covid19, jasa sosialisasi dalam menggunakan e-learning untuk upaya sebagai metode pembelajaran yang bisa digunakan saat ini, kesadaran guru bahwa adanya cara atau metode untuk mengatasi stress pembelajaran untuk siswa ketika melakukan pembelajaran online atau pembelajaran jarak jauh. Diharapkan kontribusi keilmuan dalam kajian ini terletak pada ranah utama yakni data mining dengan teknik ensemble learning. Kemudian berkontribusi juga pada bidang pendidikan terhadap situasi pandemic Covid19. Dengan begitu membuka paradigma pembelajaran pada sekolah sesuai program pemerintah saat ini dengan konsepnya merdeka belajar.

\section{METODE}

Metode yang digunakan dalam pengumpulan data yakni dengan survey langsung ke sekolah tersebut, bertemu dan berdiskusi dengan kepala sekola, guru ilmu komputer atau guru bidang komputer, melihat dan mengenal lingkungan sekolah dan hal lain yang terkait dengan data mining dilakukan dengan kepustakaan. Metode lain dengan wawancara dan kuisioner. Wawancara dapat dilakukan pada kunjungan kepada sekolah tersebut seperti yang dilakukan pada tahun 2019, selanjutnya dapat juga dilakukan dengan memberikan kuisioner yang telah disiapkan peneliti untuk guru sekolah sebagai kriteria gambaran keinginan dan penyesuaian penerapan data mining dan pengambangan data mining. Selain dari metode tersebut ada metode lain untuk melengkapi yakni dengan adanya studi pustaka yang dilakukan pada perpustakaan guna mengumpulkan informasi terkait kegiatan pengabdian masyarakat. Pengolahan data menggunakan perangkat lunak Rapidminer (Sabna 2019; Altalhi et al. 2017) . Dengan konsep data mining yakni melihat ekstraksi data dan menemukan pola data baru yang akan diartikan sehingga memberikan pola khusus yang dapat digunakan dan dimanfaatkan untuk kepentingan penerpan ensemble learning sebagai penentu stress 
pembelajaran. Metode penelitian menggunakan Knowledge Discovery in Database (KDD) terdiri dari 9 tahapan (Dhika et al. 2018; Anon 2016; Maimon \& Rokach 2012) untuk melakukan validasi dari data yang diperoleh dilakukan ujicoba atau terapan model rule yang dihasilkan. Implementasi dilakukan dengan memberikan konsep rule pada sekolah sebagai sumber informasi tentang data mining atau ensemble learning yang akan disesuaikan kembali dan dievaluasi kembali.

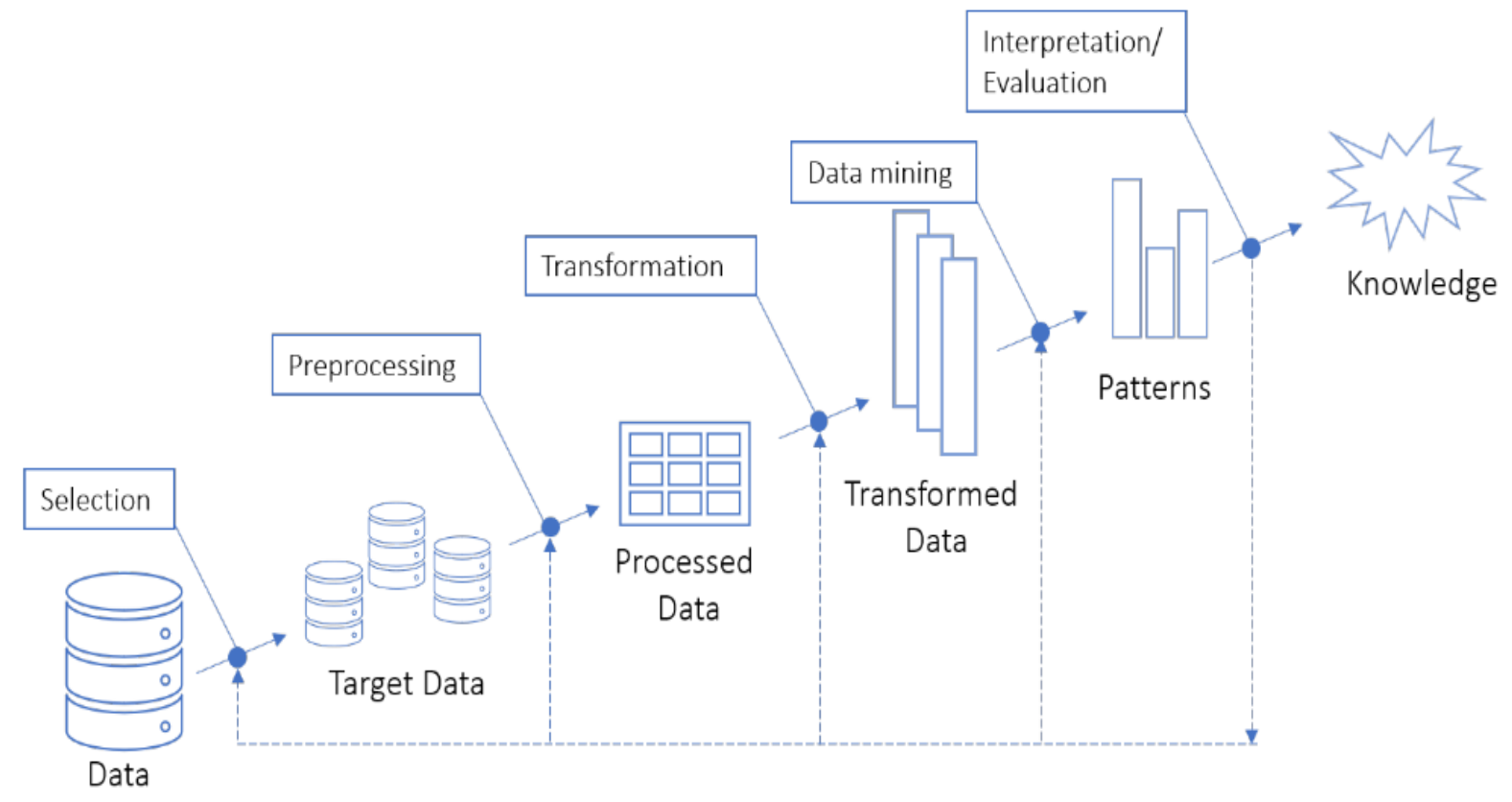

Gambar 1. Knowledge Discovery in Database (Neto et al. 2019)

Data mining dengan knowledge dapat diterapkan dalam segala bidang seperti pada gambar diatas. Namun penerapan kali ini menggunakan knowledge discovery in database (KDD). Terdapat 9 tahapan kajian dalam penelitian ini, dimulai dari Domain understanding hingga discovered knowledge. Terdapat Sembilan langkah tahapan KDD (Maimon 2010; Maimon \& Rokach 2012) 4 yakni proses terjadi secara iterative atau berulang disetiap langkah dan tahapan penelitian, mulai dari memahami sebuah domain penelitian dan goal dari sebuah kajian. KDD digunakan karena kondisi kajian yang mungkin dilakukan dapat dikembalikan ke tahap sebelumnya dimana tahapan telah berada pada bagian tengah. KDD dimulai dengan Domain aundrstanding dan KDD goal diakhiri dengan discovered Knowledge dengan visual dan integration. Tahapan KDD sebegai berikut: 1. Domain understanding dan KDD Goal, 2. Selection dan Audition, 3. Preprocessing; data clearing, 4. Tranformation, 5. Data mining, 6. Memilih algortima data mining, 7. Penerapan algoritma data mining 8. Evaluation dan Interpolation 9. Discover Knowledge. Pembahasan data mining bisa juga diterapkan dalam bidang lain, seperti pada gambar berikut (Wu et al. 2008; Zhou et al. 2020). Penerapan data mining sudah banyak sekali digunakan dalam kehidupan sehari-hari, diantaranya digunakan untuk menilai tingkat kepuasan konsumen terhadap pelayanan suatu hotel (Desyanti 2018). 


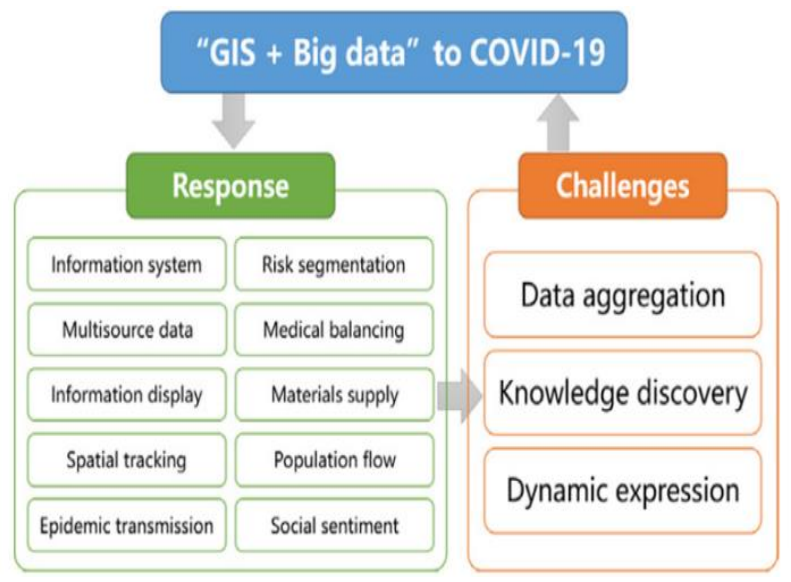

Gambar 2. Data Mining Dalam Bidang Lain (Zhou et al. 2020)

Corona Virus Disae atau Covid 19 merupakan virus yang sangat menular saat ini (Rowan \& Laffey 2020). Kegiatan pengabdian ini dilakukan pada masa Covid19 yakni dengan tujuan atau harapan bahwa dapat membantu sedikit kontribusi keilmuan dalam bidang data mining terhadap penyelesaian pandemi Covid19. Berdasarkan data yang diperoleh, berikut ini klaster wilayah penyebaran Corona Virus Disae di Indonesia.

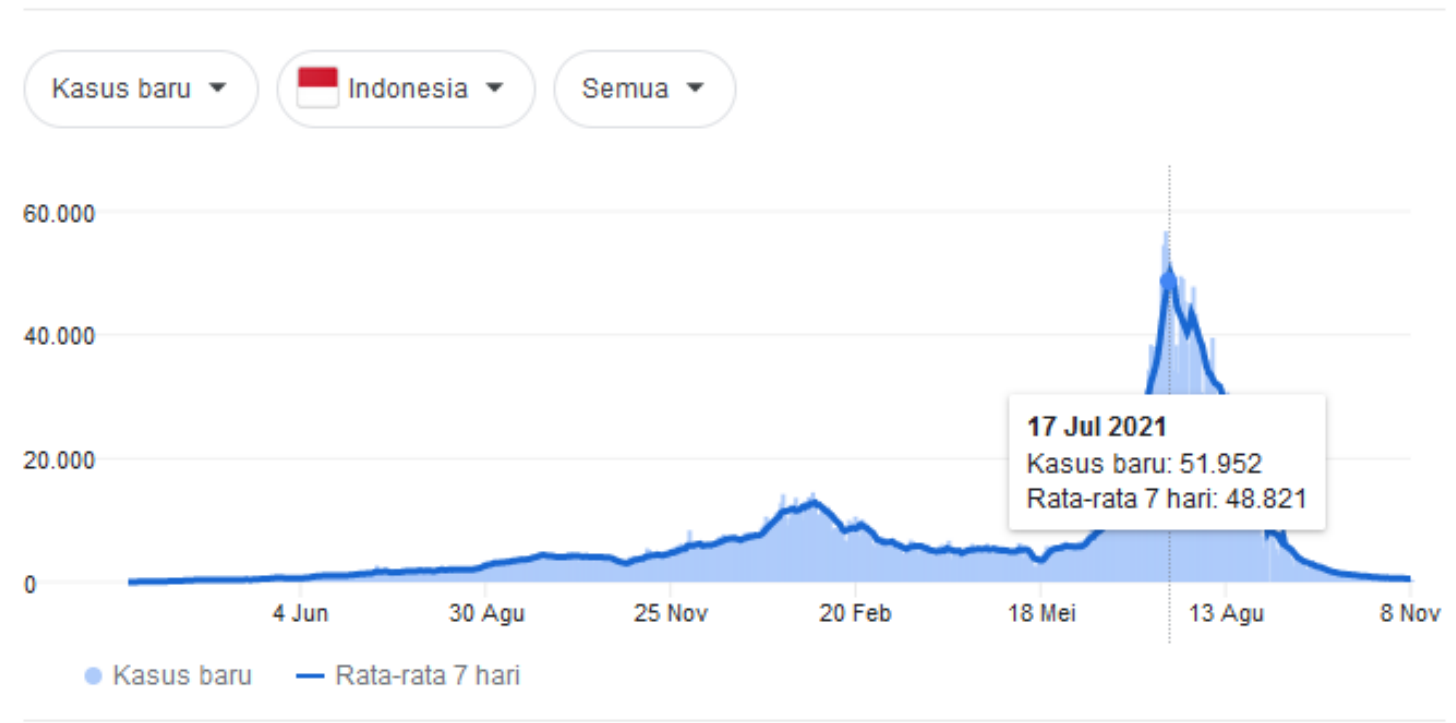

Gambar 3. Kasus Covid19 di Indonesia (JHU CSSE COVID-19 Data 2021)

Walaupun kajian utama dalam usulan ini adalah menekankan pada bidang data mining dan teknik ensemblenya namun tetap memiliki kaitan dan kontribusi kecil untuk mengentahui perkembangan pembelajaran siswa dalam masalah Covid19. Hasilnya adalah rule yang diberikan kepada pihak sekolah sehingga mengetahui sebagaimana mestinya mendesain konsep pembelajaran online selama pandemic ini. Studi pendahuluan telah dilaksanakan dan diharapkan sekolah dapat memahami pengetahuan untuk mengatasi masalah mengenai tingkat stress belajar siswa ketika masa pandemi Covid19, diharapkan pengetahuan yang sudah diterima akan memberikan dampak yang baik untuk siswa ataupun guru dalam menerapkan pembelajaran secara online. Hal ini sangat penting agar tidak terjadi stress yang berlebihan yang disebabkan oleh metode pembelajaran saat ini yang menggunakan pembelajaran jarak jauh atau pembelajaran online. Sasaran kegiatan pengabdian ini 
adalah sekolah khusunya guru dan siswa yang terlibat dalam kegiatan pembelajaran jarak jauh untuk meningkatkan kesadaran guru dan siswa dalam menggunakan teknologi khusunya e-learning, dan cara mengatasi stress dalam kegiatan pembelajaran. Hasil dari kegiatan pengabdian ini menghasilkan rule untuk mengetahui sebagimana mestinya mendesain konsep pembelajaran online selama pademi dengan mengkaji algoritma data mining dengan menerapkan terhadap data di sekolah. Data yang diperoleh dilakukan ujicoba atau terapan model rule yang dihasilkan dengan Receiver Operating Characteristic pengukuran confusion matrix.

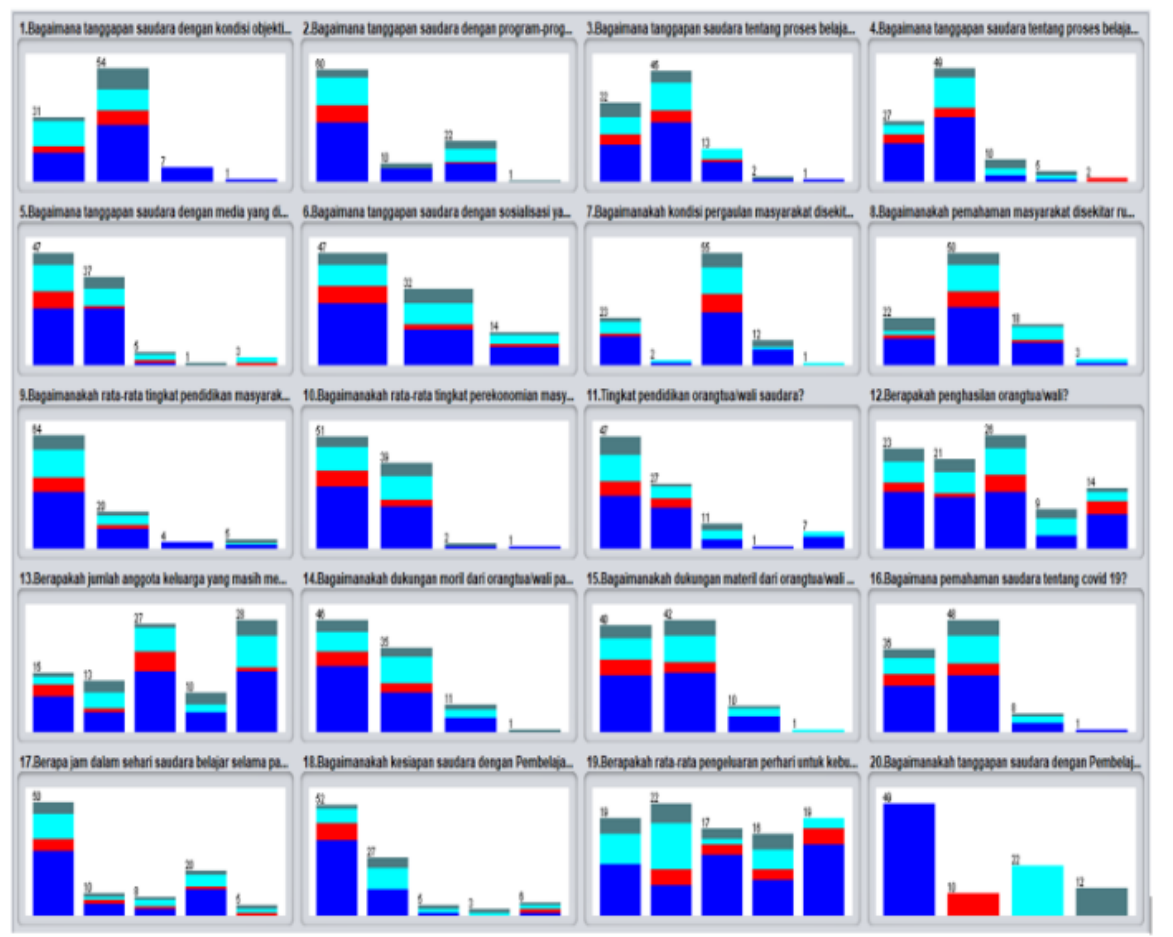

Gambar 4. Pengelolaan Data Kuesioner data olahan pribadi dengan Weka

Hasil yang diperoleh untuk mitra kami adalah pengetahuan rule dalam mengatasi stres pembelajaran ketika masa pandemi Covid19. Dari data yang telah diperoleh dan diproses menggunakan algoritma C4.5 (Sugianto 2015), Naïve Bayes dan Ensemble Learning menghasilkan rule bahwa siswa yang melakukan pembelajaran jarak jauh memiliki kondisi biasa saja dan tidak antusias dalam kegiatan pembelajaran. Rule yang diberikan kepada pihak sekolah dengan mengetahui penerapan e-learning dalam pandemi Covid19 ini merupakan sebagaimana mestinya konsep pembelajaran online yang dapat digunakan dengan maksimal untuk mengurangi stress pembelajaran dengan mengetahui hasilnya maka pihak sekolah dapat mengetahui perkembangan pembelajaran siswa dalam masa pandemi Covid19. Berikut ini penerapan pengolahan data menggunakan konsep data mining dengan algoritma C4.5, Naïve Bayes dan Ensemble Learning.

Data dalam bentuk numeric dan diskrit dapat diolah oleh algoritma C4.5, dari hasil generate terdapat beberapa atribut yang hilang, hal ini dapat degenerate sesuai keputusan pruning dengan nilai gain dan nilai entropy. Seluruh aturan sangat mudah dipahami dan diinterpretasikan dengan cepat dibandingkan algoritma lainnya. Kecepatan dan waktu yang di berikan sangat singkat dalam mengolah data yang besar. Berikut ini adalah hasil dari C4.5: 


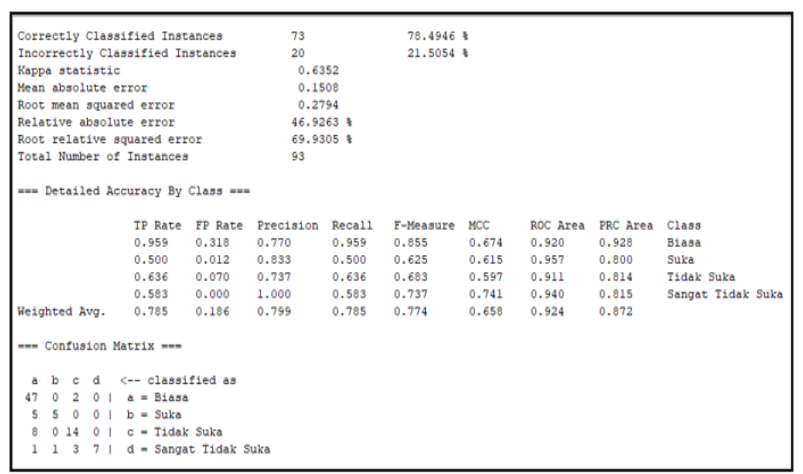

Gambar 5. Hasil Pengelolaan Data Menggunakan C4.5

Teknik ini merupakan teknik penyederhanaan dari teknik Bayesian, network clasification. Naïve bayes adalah teknik yang menggunakan konsep peluang atau probabilistik. Naïve bayes bagian dari acyclic melalui suatu variabel stachastic dan variabel diskrit. Naïve bayes memiliki keuntungan menggabungkan domain knowledge dan prior distribution sebelumnya dari sample data. Berikut ini adalah hasil dari Naïve Bayes :

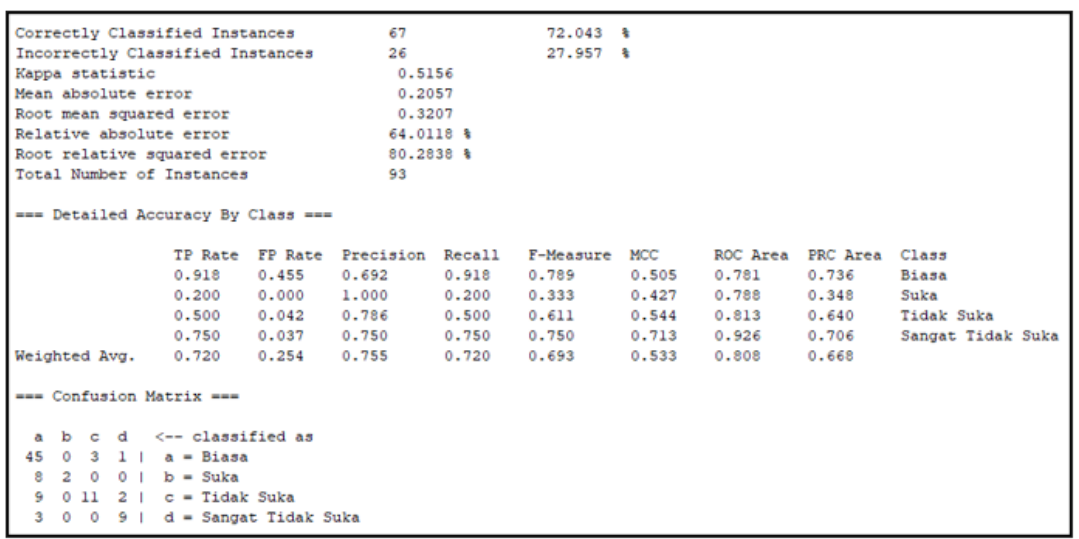

Gambar 6. Hasil Pengelolaan Data Menggunakan Naïve Bayes

Dalam membuat decision tree dibuat secara rekursif, pemilihan split attribut menjadi hal yang sangat penting dan menentukan struktur tree. Dalam membangun struktur tree menggunakan index gain, menggunakan teori entropy, dan algoritma yang terkenal adalah C4.5. Berikut ini adalah hasil dari Ensemble Learning:

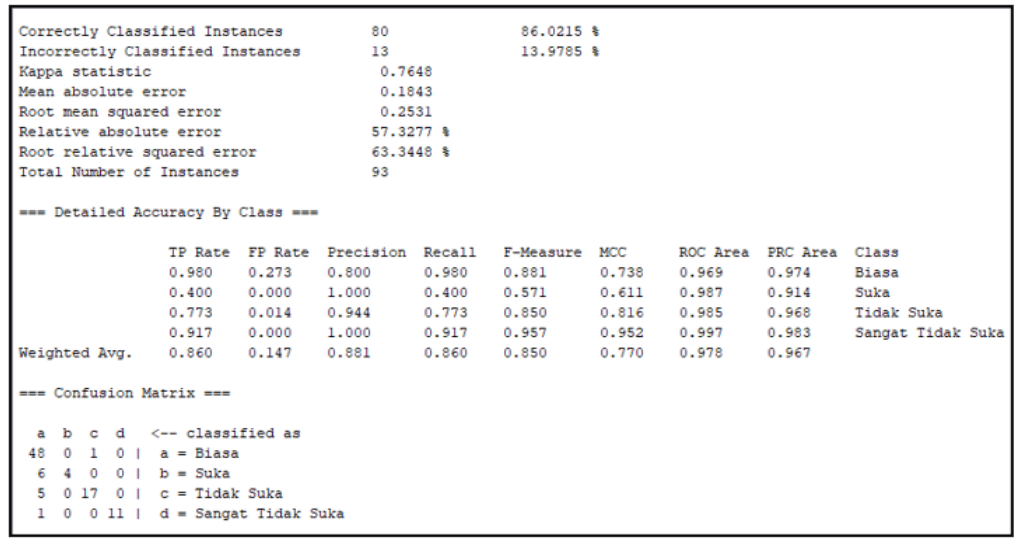

Gambar 7. Hasil Pengelolaan Data Menggunakan Ensemble Learning 
Manfaat yang diperoleh untuk mitra kami adalah pengetahuan rule dalam mengatasi stres pembelajaran ketika masa pandemi Covid19, khususnya kami berharap sangat bermanfaat bagi siswa, namun tidak menutup kemungkinan hal ini juga sebagai informasi bagi para guru sehingga civitas sekolah lebih mengetahui dan memahami kondisi yang ada(Sari et al. 2021; Gellysa Urva et al. 2021). Dari data yang telah diperoleh dan diproses menggunakan algoritma C4.5, Naïve Bayes dan Ensemble Learning menghasilkan rule bahwa siswa yang melakukan pembelajaran jarak jauh memiliki kondisi biasa saja dan tidak antusias dalam kegiatan pembelajaran. Hasilnya adalah rule yang diberikan kepada pihak sekolah dengan mengetahui penerapan elearning dalam pandemi Covid19.

\section{HASIL DAN PEMBAHASAN}

Luaran dari kegiatan pengabdian ini pada mitra kami adalah jasa penyuluhan rule atau metode dalam mengatasi stress pembelajaran ketika masa pandemi Covid19, jasa sosialisasi dalam menggunakan e-learning untuk upaya sebagai metode pembelajaran yang bisa digunakan saat ini, kesadaran guru bahwa adanya cara atau metode untuk mengatasi stress pembelajaran untuk siswa ketika melakukan pembelajaran online atau pembelajaran jarak jauh.

Dalam pelaksanaan kegiatan pengabdian ini memiliki kendala untuk memperoleh data yang dibutuhkan memerlukan waktu yang lebih lama, karena siswa dan guru melakukan semua kegiatan di rumah masing-masing dan bukan di sekolah. Tetapi hal ini dapat diatasi dengan adanya guru piket yang bertugas di sekolah, sehingga distribusi kusioner dan wawancara dapat dilakukan secara online untuk memperoleh data yang akurat. Faktor yang mendukung dalam kegiatan ini adalah guru wali kelas yang berperan aktif memberikan dan mengarahkan kuisioner yang harus diisi dengan keadaan siswa saat melaksanakan pembelajaran jarak jauh atau pembelajaran online.

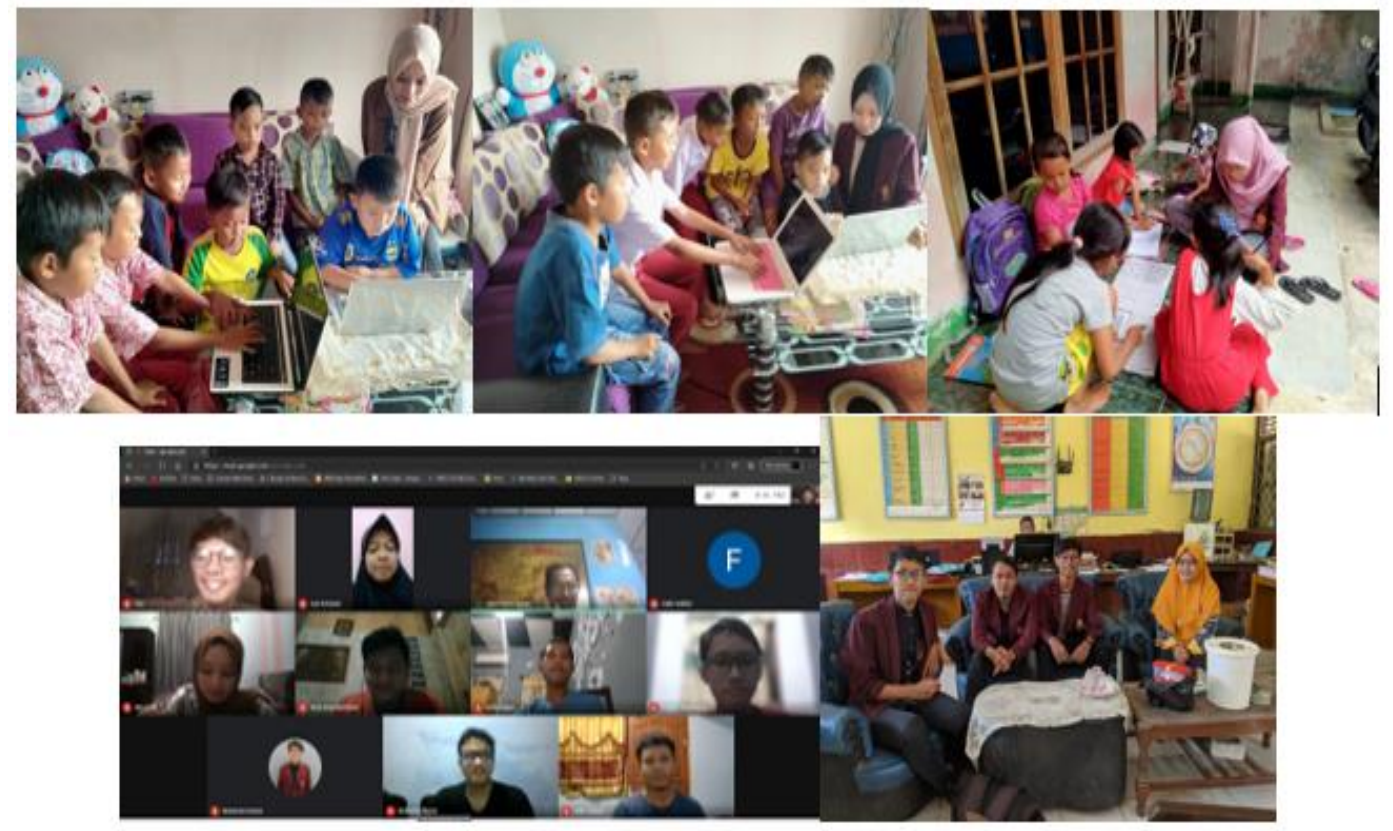

Gambar 8. Percobaan Pendampingan Implementasi Hasil Pengelolaan Data Menggunakan Ensemble Learning 


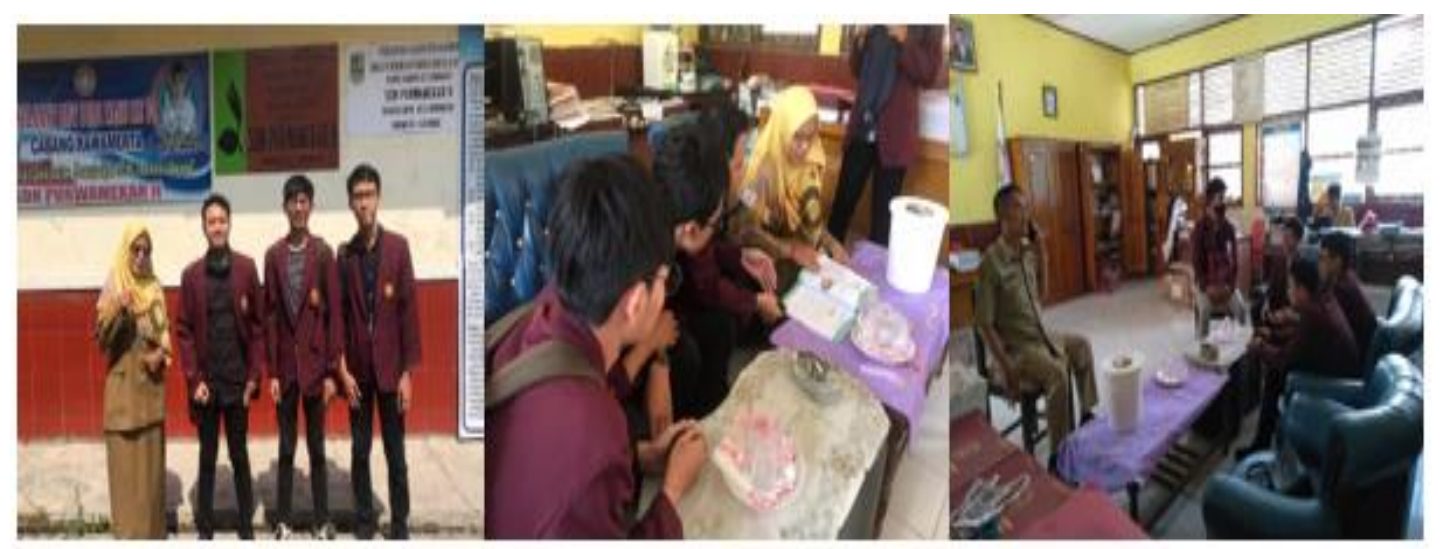

Gambar 9. Pendampingan Kegiatan

Rencana tindak lanjut untuk mitra kami adalah penentuan hasil identifikasi untuk rule yang telah dihasilkan, dimana sekolah wajib mengubah metode pembelajaran jarak jauh yang sedang dilakukan saat ini. Diharapkan dengan dirubahnya metode pembelajaran jarak jauh dapat maksimal dilakukan secara online dengan cara yang berbeda dan interaktif. Evaluasi masalah dan solusi pemecahan masalah ini dapat dilakukan oleh guru dalam memberikan pembelajaran secara online agar dapat dilakukan secara interaktif.

\section{KESIMPULAN}

Kegiatan pengabdian kepada masyarakat ini membahas mengenai penerapan ensemble learning sebagai penentu stress pembelajaran pada Sekolah Menengah Atas (SMA) dalam kota Karawang. Metode yang digunakan yakni 9 langkah KDD, evaluasi menggunakan kurva ROC dan dilakukan pengukuran presisi data serta akurasi data maka dengan nilai presisi data yang tinggi dan akurasi yang tinggi maka dapat disimpulkan kategori klasifikasi yakni sangat baik. Hasilnya adalah rule yang diberikan kepada pihak sekolah dengan mengetahui penerapan elearning dalam pandemi Covid19 ini merupakan sebagaimana mestinya konsep pembelajaran online yang dapat digunakan dengan maksimal untuk mengurangi stress pembelajaran dengan mengetahui hasilnya maka pihak sekolah dapat mengetahui perkembangan pembelajaran siswa dalam masa pandemi Covid19.

\section{UCAPAN TERIMA KASIH}

Ucapan terima kasih terutama Universitas Singaperbangsa yang telah memebrikan dukungan dana dalam melakukan kegiatan ini, dan Ucapan terima kasih kepada pihak-pihak yang membantu pelaksanaan penelitian (SMAN 3 Karawang dan SMAN 5 Karawang).

\section{DAFTAR PUSTAKA}

Altalhi, A.H. et al., 2017. Evaluation and comparison of open source software suites for data mining and knowledge discovery. Wiley Interdisciplinary Reviews: Data Mining and Knowledge Discovery, 7(3), pp.e1204-e1204.

Anon, 2016. Data Mining: Practical Machine Learning Tools and Techniques,

Ardakani, A.A. et al., 2020. Application of deep learning technique to manage COVID-19 in routine clinical practice using CT images: Results of 10 convolutional neural 
networks. Computers in Biology and Medicine, 121(March), p.103795.

Desyanti D, 2018. SATIN - Sains dan Teknologi Informasi Penerapan Data Mining Algoritma C4 . 5 untuk Mengetahui Tingkat Kepuasan Konsumen di Hotel Grand Zuri Dumai. , 4(2).

Desyanti, D. (2021) "Implementasi Metode C.45 dalam Menganalisa Tingkat Kecemasan Mahasiswa Menyusun Tugas Akhir ”, JURNAL UNITEK, 14(1), pp. 17-29. doi: 10.52072/unitek.v14i1.175.

Dhika, H., Destiawati, F. \& Fitriansyah, A., 2018. Implementasi Algoritma C4. 5 terhadap Kepuasan Pelanggan. SNAPP 2016, Vol. 6(Sains dan Teknologi), pp.1622.

Gellysa Urva, Pratiwi, M. \& Oemara Syarief, A., 2021. E-Learning berbasis Edmodo untuk Optimalisasi Pembelajaran Pada Masa New Normal. ABDINE: Jurnal Pengabdian Masyarakat, 1(1), pp.41-47.

JHU CSSE COVID-19 Data, 2021. Statistik Kasus Baru dan Kematian Covid19 di Indonesia.

Maimon, O., 2010. Data Mining And Knowledge Discovery Handbook Second Edi. Prof. Oded Maimon, ed., Israel: Springer US.

Maimon, O. \& Rokach, L., 2012. Data Mining and Knowledge Discovery Handbook,

Neto, C. et al., 2019. Application of data mining for the prediction of mortality and occurrence of complications for gastric cancer patients. Entropy, 21(12).

Rowan, N.J. \& Laffey, J.G., 2020. Challenges and solutions for addressing critical shortage of supply chain for personal and protective equipment (PPE) arising from Coronavirus disease (COVID19) pandemic - Case study from the Republic of Ireland. Science of the Total Environment, 725, p.138532.

Sabna, E., 2019. PEMANFAATAN DATA MINING UNTUK PENEMPATAN BUKU DI PERPUSTAKAAN MENGGUNAKAN METODE ASSOCIATION RULE. Jurnal Ilmu Komputer, 8(2), pp.59-63.

Sari, F. et al., 2021. Pelatihan Pembuatan Media Pembelajaran Sempoa Berbasis Teknologi Informasi. ABDINE: Jurnal Pengabdian Masyarakat, 1(1), pp.14-19.

Sugianto, C.A., 2015. Penerapan Teknik Data Mining Untuk Menentukan Hasil Seleksi Masuk Sman 1 Cibeber Untuk Siswa Baru Menggunakan Decision Tree. TEDC, 9, pp.39-43.

$\mathrm{Wu}$, X. et al., 2008. Top 10 algorithms in data mining,

Zhou, C. et al., 2020. Geography and Sustainability COVID-19 : Challenges to GIS with Big Data. Geography and Sustainability, 1(1), pp.77-87. 